\title{
College Students Volunteer Service: a Platform for Carrying out the Effective Practice of Citizen Education in Colleges and Universities
}

\author{
Tianyun Pei \\ Department of Economic Management \\ North China Electric Power University \\ Baoding, China \\ hdpeity@126.com
}

\begin{abstract}
The citizen education is an important method to coordinate, as well as improve and promote the relationships between citizens and the country, the government, society in daily life, and it can effective enhance the overall level of citizens. As an important place of civic education, the colleges and universities are responsible for students with the educations of civic values, citizens' knowledge, independent personality and subjectivity. The purpose of citizen education is that the educated people give their knowledge back to the society, and the effective way is the volunteer service as the achievements. College students who have done civic education carry out extensive volunteer service, not only for their own personality sublimation, but for the identification of the emotion and practice of civic education.
\end{abstract}

Keywords-Component; Citizen Education; Volunteer Service; Ideological and Moral Education; College Students; Universitiy

In recent years, "civil education" is repeatedly stressed by the Party and the government. Report of the 17th national congress proposed to "strengthen citizen consciousness education, set up the socialist concept of democratic rule of law, freedom, equality, fairness and justice". From both the views of sociological, civic consciousness and social responsibility, colleges and universities, as a carrier of undertaking public education, should strengthen the enthusiasm of college students to engage in social work, enhance the opportunities for young people to participate in the volunteer practice.

\section{CITIZEN EDUCATION}

Citizens in the modern sense are the natural persons who are eligible to participate in the political life, the legal life, and the public life, and being politically independent with the corresponding rights and obligations. In order to implement the constitutional definition of citizenship, citizens are also required to have citizenship. The cultivation of civic awareness needs to be completed by civic education. Civic education is a universal education in the face of all citizens, including politics, behavior, law, morality and so on.

Western Civic Education Center is through the political education, social education, the formation of civic awareness. China's civil education started later, the rise of this before and after the five four. Xia Shizhong, Tang
Jiang (2006) the core definition of civic education is, in the social adjustment the relationship between the individual and the government's education. The purpose is to achieve the political, legal and moral daily. Huang Wai, Huang Xiaoting (2009) from the perspective of social definition, civic education is to make personal socialization, in line with social policy. Under the perspective of sociology, civic education is focused on the formation, maintenance and development of the civil society and each point is a reflection of the urgent need of the citizen education. High wind (2002) the civic education is divided into three points: first, the cultivation of civil law view; the two is to face the right and obligation to the same; the three is to develop the quality of citizens: democratic life, equality spirit. Ao Jie (2013) defines the target of civic education is mainly developed to contribute to the community, contribute to the social development of the people. Civic education has the characteristics of life, popularization and foundation.

In summary, the broad sense of citizenship education is the national investment, through a variety of ways, training can have a sense of patriotism, democracy and the rule of law, to participate in social life, self management, with independence, innovative people, and will learn to repay society. By receiving education, social practice, to achieve the upgrading of the outstanding citizens from natural persons to citizens.

\section{VOLUNTEER SER VICE}

The United Nations Educational, scientific and Cultural Organization for the "voluntary service" is defined as: "voluntary service is an altruistic behavior, refers to people in the formal (non private) occasions, in a period of time and free to contribute their time and expertise".The origin of voluntary service and the west, the first for the religious charity. Refers to the use of time, pay the skills, resources, with friendly neighbors, community, social behavior to make free contribution. London "charity organization society" American Association of social workers, India missionaries will volunteer service pioneer institutions.

Foreign research on the voluntary service started earlier. Louis.A.Penner to distinguish between voluntary service and helping behavior, the non replication of the voluntary service is its discretion, continuity, full voluntary. In modern China, Lei Feng spirit is a pioneer in the voluntary service, in the ideological and moral education for the socialist country, the core of Lei Feng's spirit is to serve the people. And voluntary service in the perspective of 
equality, selfless, embodies the core of Lei Feng's spirit of dedication, and the two are similar. China's voluntary service started in 1990s, the introduction of Hongkong, initially called the "volunteer". 1994 China volunteers association was founded, formally determined the volunteer service. Domestic scholars have a wide range of research on voluntary service. Ding Yuanzhu, Jiang Xunqing (2001) think, volunteer work, volunteer service is refers to this as volunteer personal time and effort, give full play to the subjective initiative, access to non physical reward, to promote the improvement of living conditions, promote social peace and happiness of the people, human culture progress of services. Liang Wei (2015) defined voluntary service for people from the subjective will, do not seek to return the altruistic behavior. Wang Hongsong (2011) will volunteer service is divided into three modes: first, the official support; two is foreign NPO support; three is informal, without the certification of simple voluntary organizations.

In summary, volunteer service through voluntary behavior, regardless of differences in status, closer to the between person and person distance, strengthen the trust between people, equality, reciprocity, is every citizen has equal use of social resources and the right to participate in social life.

\section{VOLUNTEER SERVICE IS THE LANDING POINT OF CITIZENSHIP EDUCATION}

\section{A. Voluntary Service to Deepen Students' Self Awareness of College Students}

Linglongta nowadays college students tend to stick to the campus, there is a big gap in theory and reality, self limitation of cognition. The process of College Students' service society is a process of mutual information exchange between the volunteers and the audience. This process, compared to the simple and simple environment of the campus, college students are really touching, feeling the true color of the community. In the rational analysis and perceptual knowledge, the care, help, communication to achieve self cognition. To eliminate the influence of "utilitarian" and "false altruism", establish a scientific world view and personality meaning, and bring the value of the individual and the whole.

First, after the civic education, citizens take the initiative to improve as a volunteer. Wenchuan Sichuan earthquake and the Beijing Olympics as an example, in Wenchuan after the earthquake in college students active enrollment into volunteers, in the aftershocks continue, the communication equipment is outdated, the signal is not stable, health conditions and other great inconvenience, excluding personal security, the first time came to the affected areas to support. Students show positive help, for the spirit of touching social interests. In this process, the college students' self perception is from the protection of the protector, from the weak to the strong, from the enjoyment of social resources to the creation of social resources.

Second, after college citizenship education, college students' volunteer service spirit of the ordinary people, every citizen is engaged in volunteer service. In China for the rectification of air pollution as an example, members of the public in serious pollution, consciously reduce motor vehicle travel, for the government to implement the odd and even numbers limit line policy, for example, people sacrifice a comfortable way to travel, abide by the temporary traffic control, itself is selfless contributions to urban construction. In this act, the people themselves are not volunteers, but the scope of their work has been reached. The people's voluntary service is a reflection of the improvement of the citizen's self cognition, and it is the highest embodiment of the implementation of civic education.

\section{B. Volunteer Service to Promote Participation in Skills Education}

Modern professional services in the field of more and more business scope, the practical ability, the higher quality requirements, which is the youth to participate in the community to provide more opportunities, greatly expand the ability of College students. Take the 2008 Beijing Olympic Games as an example, which takes the majority of university students' community as the volunteer source. Volunteer service is to cultivate the spirit of service, improve students' social ability. College students play the relevant knowledge, mutual influence, mutual learning, not only a successful completion of the voluntary service, but also to accept social skills education. And social skills education is an important aspect of civic education. College students participate in volunteer service, seemingly at the expense of time, money and energy. However, volunteer service is a hands-on process set an example by personally taking part. Services, college students can learn life knowledge, social skills. Get friendly, confident, and dedication of the healthy personality. This and the knowledge in the university is complementary to the book, the practice of perception, is greatly improved the competitiveness of College students. In the voluntary service middle school will manage themselves, management of others, business relations have also contributed to the university students after graduation, the employment unit of the value. At the same time, good social skills feedback in the construction of civil environment has a high value.

\section{Volunteer Service is an Important Way of College Students' Moral Education.}

The core content of civic education is the improvement of citizen's moral level. Civic education outstanding morality education, the educated to develop civilized, polite, honest and trustworthy, mutual affection of national quality and the maintenance of social security and public order, environmental protection and other good habits. In Colleges and universities, civic education and ideological and moral education is often bundled together. However, the modern university education is too much emphasis on the ideological and theoretical education and neglect of ideological education practice, college student volunteer service is an important civic moral education. Volunteer service is to enhance the ideological and moral cultivation, the oral politics lesson into a kind of education mode of College Students' voluntary participation in the process of service, stimulate the inner potential of love, dedication, care, social services, mutual cooperation, cooperation and other moral qualities. To combine the spirit of serving the people and the moral content of the citizens, to improve their moral character, the spirit is bright. It is the effective 
way of citizen moral education to put the volunteer service into the ideological and political education, which is not only in line with the basic idea of civic education, but also the reality of the situation.

Contemporary college students' volunteer spirit is the ideological and moral education of citizens, inheriting and carrying forward the Chinese mutual help, respect for teachers and other traditional virtue, on the other hand, equality, love the socialist ideological and moral construction of contemporary China's political and social life which produce the positive influence

\section{REFERENCES}

[1] ZhuLiLing. Volunteer service: a new approach to the education of young people [J]. Journal of Beijing Youth Politics College, 2009, 18:2.

[2] ShiHuiYong, ZhangHaiBin. Youth Volunteer Service: an effective way of civic education in Colleges and Universities [J]. News world, 2010, 11: 112-113.

[3] XiaShiZhong, Tang JiAng. From the perspective of the operation of the lack of civic education in Colleges and Universities [J].Adult education in Chinav, 2006 (3):58.
[4] AoJie.Research on the Effectiveness of Citizenship Education for Chinese College Students[D] Hunan Normal University 2013

[5] GaoFeng. Citizenship and civic education and ideological and Political Education [J]. Northeast Normal University Journal, 2002, 04: 40-49.

[6] HUANG Wei, HUANG Xiao-ting. A Decade of Citizenship Education in China: Retrospect and Prospect [J]. Tsinghua Journal of Education, 2009, 30: 100-109.

[7] Liang Wei. Research on theSchool voluntary Service and the Function of Civic Education [J]. Journal of Zhangiakou Vocational and Technical College, 2015, 06: 29-31.

[8] DingYuanZhu,JiangXunQing. Volunteer activity research: type, evaluation ,management.Tianjin people's Publishing House 2001:2-3

[9] LouisA.Penner.Volunteerism and Social Problems: Making Things Better or Worse .Journal Of Social Issues, Vol.60, No.3. (2004), p.645-666.

[10] WangHongSong, OLUNTEER SER VICE AND CONSTRUCTION OF CIVIL SOCIETY IN CONTEMPORARY CHINA [D]China University of Policial Science and Law 2011

[11] GongWanDa. On the Research of Voluntary Service in Vision of social Ecology [D]. ShangHai University ,2011

[12] GaoCuiXin.Study on the Moral Education of Lei Feng Spirit for Modern College Students[D]China University of Geosciences 2014 